\title{
OSMOREGULATION AND ANTIMICROBIAL ACTIVITY OF TWO EGYPTIAN TRUE XEROPHYTES; LAUNAEA SPINOSA (FORSSK.) AND LEPTADENIA PYROTECHNICA (FORSSK.)
}

\author{
Zeinab A. Khidr*, Fawzia A. Ebad and Hend A. El-Khawaga \\ Department of Botany and Microbiology, Faculty of Science, Al-Azhar \\ University (Girls Branch), Cairo, Egypt \\ *E-mail: zenib@azhar.edu.eg
}

\begin{abstract}
T $\mathrm{n}$ the present work, some of the adaptive responses against dehydrative factors were evaluated in two true xerophytic plants, for their medicinal importance; [Launaea spinosa (Forssk.) Sch. and Leptadenia pyrotechnica (Forssk.) Decne.] growing naturally (wild plants) at Wadi Hagul, Eastern Desert of Egypt during both wet and dry seasons. The results reveled that Launaea spinosa achieved the highest significant ash concentration during the dry season and this was mainly due to accumulation of $\mathrm{Na}^{+}, \mathrm{K}^{+}, \mathrm{Cl}^{-}$and $\mathrm{SO}_{4}{ }^{2-}$, meanwhile the opposite was found in Leptadenia pyrotechnica, which accumulated $\mathrm{Ca}^{2+}, \mathrm{Mg}^{2+}$ and $\mathrm{P}^{3+}$ during the wet season. The highest significant concentrations of total carbohydrates, insoluble sugars as well as phytohormones were recorded during the wet season, while organic acids, free thiols, total fibers, and soluble sugars were accumulated, in both species, during the dry season. From the results it is clear that, ethyl acetate extracts for both species possessed the highest antimicrobial activity against all tested fungal and bacterial strains. The obtained results showed that the studied species have different mechanisms to adapt and tolerate the various environmental conditions.
\end{abstract}

Keywords: antimicrobial activity, drought, free thiols, inorganic and organic osmotica, phytohormones, true xerophytes

The quality of traditional medicine, which plays a very important role in the health system of Egypt, is determined by its active substances produced by the plants. Most of these plants are xerophytes. The selected species for this 
study belong to both families, Asclepiadaceae and Asteraceae (Compositae). Many medicinal plants contain large concentrations of antioxidants, which can play an important role in neutralizing free radicals (Anderson et al., 2001 and Nisa et al., 2013). Many of Launaea species (family Asteracea) are used in folk medicine as hepatoprotective, bitter stomachic, for treating skin diseases, and reported to have antitumor, insecticidal and cytoprotective activities (ElBassuony and Abdel-Hamid, 2006 and Khan et al., 2012). This genus is rich in different secondary metabolites, such as terpenoids (Abdel Fattah et al., 1990), phenolic compounds (Abdallah et al., 2015) and coumarins (El-Bassuony and Abdel-Hamid, 2006). Abdallah et al. (2015) reported that some of Launaea species are used traditionally to treat liver oxidative stress. The potential cytoprotective activity of phenolic compounds isolated from L. spinosa was assessed against oxidative stress induced by tert-butyl hydroperoxide (t-BHP) in HepG2 cells in order to relate in vitro antioxidant activity with cytoprotective effect. It has been found that the major phenolic compounds isolated from $L$. spinosa displayed a significant cytoprotective effect against oxidative stress, leading to maintenance of the normal redox status of the cell.

Plants belonging to the family Asclepiadaceae are frequently used in traditional medicine and have been reported to be rich in steroidal glycosides, alkaloids, flavonoids, triterpenes and polyoxypregnane derivatives (Sharma et al., 2016). The plants of this family are known to contain cytotoxic and tumoricidal C/D-cis-polyoxypregnane esters and glycosides. The branches, leaves and bark of Leptadenia pyrotechnica are used in folk medicine to prepare antispasmodic, anti-inflammatory, antihistaminic, antibacterial, diuretic, uroliths expulsion, expectorant, gout and rheumatism remedies (Panwara and Tarafdarb, 2006). The plant is a typical desert shrub growing in different regions of Egypt, especially in the Eastern Desert and Sinai Peninsula. It is known in the Arabic language as Markh, Assabay and Kalenba (McLaughlin, 2006).

In the arid and semi-arid deserts, most plants are exposed to water stress due to extreme soil moisture deficits. Under severe water stress conditions caused by salinity and/ or drought, plants stop growing completely and accumulate solutes in their tissues in order to maintain the cell volume and turgor against dehydration. This phenomenon is known as osmotic adjustment (Patakas et al., 2002). Drought resistance is a complex trait involving several interacting processes (Scholz et al., 2012). The adaptation in desert plants is due to their ability to maintain their turgidity and water uptake. The most important mechanism, to maintain the water potential of plants more negative than the surrounding medium, is the ability of plants to accumulate high concentrations

Egyptian J. Desert Res., 67, No. 2, 331-349 (2017) 
of inorganic ions inside their tissues (Ismaeil et al., 2006 and Abdel Kawy, 2015). The plants also tend to accumulate the most compatible solutes in the cytoplasm to balance the osmotic pressure inside the cells, especially by increasing their content of organic solutes (Khidr et al., 2007 and Salama et al., 2017).

Phytohormones play vital roles in drought tolerance of plants. Under drought, auxins, gibberellins and cytokinins usually decreased, while abscisic acid increased (Farooq et al., 2009). Li et al. (2003) reported that increased levels of IAA due to $\mathrm{GA}_{3}$ spraying delayed the biosynthesis of lignin and induced more vigorous growth in bayberry leaves. A reduction of cytokinins from the root alters gene expression in the shoot and thereby elicits appropriate responses to alleviate the deleterious effects of stress. It was indicated that transcription of stress-inducible genes can also be caused by cytokinin application. This indicates the possible roles for cytokinin in affecting the overall hormonal balance following the imposition of environmental stress (Hare et al., 1997 and Abdel Kawy, 2015)

This work aimed to study the adaptive responses in two of nonsucculent xerophytes (Launaea spinosa and Leptadenia pyrotechnica), which grow naturally at Wadi Hagul (Eastern Desert of Egypt), to cope with their habitat conditions. Also, to evaluate the antimicrobial activity of both aerial parts of shoot extracts and latex.

\section{MATERIALS AND METHODS}

The present study was done to identify the adaptive responses of two true xerophytic species under abiotic stress conditions during wet and dry periods along Wadi Hagul (Eastern Desert of Egypt). The Wadi receives drainage water from western and southern slopes of Gebel Ataqa (range 500 to above $800 \mathrm{~m}$ ). It drains to the Gulf of Suez, $48 \mathrm{~km}$ South of Suez passing through the coastal land to the sea. The selected plant species comprised: Launaea spinosa and Leptadenia pyrotechnica, which are non-succulent perennial xerophytes. The samples of plant species as well as the associated soils were taken during the dry period (July) and the wet period (February) of the year. For L. spinosa, The plant was collected from a water runnel traversing the terraces and flowing into Wadi Hagul. It was the dominant species of a community type including Erodium bryoniae, Zilla spinosa, Ochradenus baccatus and Lygos raeta as associated species. For L. pyrotechnica, The plant was sampled from a community type dominated by Retama raetam covering the 
old terraces of the wadi close to the bounding hills. Associated species include Farsetia aegyptiaca, Trichodesma africana, Zilla spinosa and Zygophyllum decumbus. The collected fresh plant materials were preserved in liquid nitrogen and kept frozen for determination of phytohormones and free thiols. Oven dried plant materials were used for mineral ions, fibers, organic acids and carbohydrate fractions estimations. Air dried materials were put into practice for antimicrobial activity.

\section{Estimation of Minerals, Ash and Fiber Concentrations}

Dry plant material was digested according to the method of Rowell (1994). The acid digest of the plant materials was analyzed for the determination of $\mathrm{Na}^{+}, \mathrm{K}^{+}, \mathrm{Ca}^{2+}, \mathrm{Mg}^{2+}$ and $\mathrm{P}^{3+}$. Sodium and potassium were estimated by flame photometry. Meanwhile, $\mathrm{Ca}$ and $\mathrm{Mg}$ were determined according to Rowell (1994). Phosphorous concentration was determined as described by Humphries (1956). The results were expressed as g/100g dry weight. The dry powdered plant materials were ashed, for $\mathrm{Cl}^{-}$and $\mathrm{SO}^{2-}{ }_{4}$ estimation according to Jackson and Thomas (1960) and Rowell (1994), respectively. Fibers were estimated as reported by British Pharmacopoeia (1980). The results were expressed as g/100 g dry weight.

\section{Determination of Carbohydrate Fractions}

The total carbohydrates were extracted according to Smith et al. (1964) and estimated colorimetrically by anthrone technique as described by Umbrient et al. (1969). Reducing sugars were extracted by phenol water and trichloroacetic acid according to Said and Naguib (1964) and estimated by the method described as A.O.A.C. (2000). Soluble sugars were extracted with ethanol/water $(80 \% \mathrm{v} / \mathrm{v})$ under reflex and estimated using the general phenol sulphuric acid method as described by Chaplin and Kennedy (1994). The difference between the percentage of total carbohydrates and soluble sugars, give the percentage of insoluble sugars. The difference between the percentage of total soluble sugars and reducing sugars was taken as the percentage of nonreducing sugars. The results of carbohydrate fractions were expressed as $g / 100 \mathrm{~g}$ dry weight.

\section{Estimation of Total Organic Acids and Free Thiols}

Total organic acids were extracted and estimated as described in A.O.A.C. methods (2000). The results were expressed as $\mathrm{g} / 100 \mathrm{~g}$ dry weight. The free thiol compounds were estimated by the method of Ellman (1959) and the

Egyptian J. Desert Res., 67, No. 2, 331-349 (2017) 
results were expressed as $\mu \mathrm{M} / \mathrm{mg}$ fresh weight.

\section{Extraction and Estimation of Phytohormones}

The extraction of growth regulators was carried out according to Gazit and Blumenfeld (1970). Indol acetic acid (IAA) was estimated by the method described by Harbor and Aasheim (1962). Estimation of cytokinins was carried out according to Fletcher and McCullagh (1971) by colorimetric determination of chlorophyll levels produced from kinetin application on cucumber cotyledons, the concentration was expressed as $\mu \mathrm{g} / 100 \mathrm{~g}$ fresh weight. Gibberellins were estimated using phosphomolybdic acid reagent, according to the method applied by Graham and Henderson (1961), their concentration and IAA was calculated as $\mathrm{mg} / 100 \mathrm{~g}$ fresh weight of plant material.

\section{Determination of Antimicrobial Activity}

Fresh plant material (aerial parts) of Launaea spinosa and Leptadenia pyrotechnica were collected in bulk, during dry season, cleaned thoroughly with distilled water and subsequently dried under shade. The shade dried shoots were pulverized in a mechanical grinder to obtain coarse powder. The latex of Leptadenia pyrotechnica was collected from the plant in the field in brown glass bottles then kept immediately in dry ice. This was done by cutting the plant at the tip pod-stem and/or fruit-stem junctures. Powdered plant material was successively extracted with different solvents (diethyl ether, chloroform, ethyl acetate, acetone, methanol and water) according to the method of Mishra et al. (2010). The latex was collected and extracted as described by Kareem et al. (2008).

The effect of Launaea spinosa and Leptadenia pyrotechnica extracts as well as the latex extract of the latter on the growth of some microorganisms were studied. Eight microorganisms were used in this study as test organisms comprising clinical isolates of four bacteria (Escherichia coli, Staphylococcus aureus, Pseudomonas aeruginosa and Bacillus subtilis) and four fungi (Aspergillus funigatus, Candida albicans, Geotrichum candidum and Syncephalastrum racemosum). The antifungal activity was done by agar well diffusion method (Rathore et al., 2000). Clotrimazole and Itraconazole were used as antifungal standard drugs. Antibacterial activity was investigated according to Rahman et al. (2001). Each inhibition zone was measured three times by caliper to get average value. The test was performed three times for each bacterium culture: Penicillin $G$ and Streptomycin were used as antibacterial standard drugs. 


\section{Statistical Analysis}

Significant differences between values of different parameters under dry and wet seasons, were found at $P \leq 0.01$ by Tukey's test (t-test), using Sigma Plot 12.5 Software.

\section{RESULTS AND DISCUSSION}

\section{Concentration of Minerals, Ash and Fibers}

During the dry season higher significant accumulation of sodium, potassium, chloride and sulphate was found (Table 1) relative to that of the wet season. Xerophytes accumulate large quantities of $\mathrm{K}^{+}$, which may play a role in drought adaptation under stress conditions. Potassium is a major plant macronutrient that plays important roles in stomatal behavior, osmoregulation, enzyme activity, cell expansion, membrane polarization and drought resistance (Elumalai et al., 2002 and Wang et al., 2004). $\mathrm{Na}^{+}$is a beneficial element, which can promote growth of many plants, in particular when $\mathrm{K}^{+}$concentration in the growth medium is limited (Box and Schachtman, 2000). Sodium is the predominant soluble cation in many of the soils of arid and semi-arid areas. Increased $\mathrm{Cl}^{-}$concentrations under dry conditions matches with the result obtained by Morsy et al. (2016), who reported that Asphodelus aestivus attained higher level of $\mathrm{Cl}$ - under dry conditions. Increased $\mathrm{SO}_{4}{ }^{2-}$ concentration during dry season matches with the results of the previous author for other xerophytes. Sulfur is an essential element for all living organisms. In plants it is found in two amino acids that are essential components of proteins, in iron-sulfur clusters and in a broad variety of biomolecules; such as vitamins, cofactors, peptides (glutathione and phytochelatins) and secondary products. Such molecules are involved in a multitude of essential biochemical and physiological processes thought to be of crucial importance for growth, crop yield and for adaptation to the adverse environmental conditions (Nocito et al., 2007). Concentrations of $\mathrm{Ca}^{2+}$ and $\mathrm{Mg}^{2+}$ were significantly lower in the dry season than in the wet ones, in both studied species (Table 1). This result supports that obtained by Abdel Kawy (2015). This may be due to accumulation of $\mathrm{Ca}$ and $\mathrm{Mg}$ in the root for osmoregulation, while $\mathrm{K}$ with higher mobility translocated to the shoot and/or due to antagonistic effect. Kirnak et al. (2003) reported that water stress could cause $\mathrm{Ca}$ reduction and suggested antagonistic effects of $\mathrm{Ca}$ uptake with $\mathrm{K}$. Calcium channels may be not entirely $\mathrm{Ca}^{2+}$ selective but also permeable to other

Egyptian J. Desert Res., 67, No. 2, 331-349 (2017) 
cations like $\mathrm{K}^{+}$. On the molecular bases, the genes encoding plasma membrane $\mathrm{Ca}^{2+}$ channels remain less well-clarified (Vahdati and Lotfi, 2013). Calcium is important in membrane stabilization and activates calmodulin protein, which initiates other events leading to several developmental and physiological responses in plants (Hopkins and Hüner, 2004), particularly under stress (Waraich et al., 2011). Although $\mathrm{Mg}^{2+}$ was plenty in the soil over $\mathrm{K}^{+}$, its concentration in the shoot of L. pyrotechnica was less than $\mathrm{K}^{+}$in both seasons. Under drought conditions $\mathrm{K}^{+}$concentration was more than 4 folds that of $\mathrm{Mg}^{2+}$, which may be explained as the case of $\mathrm{Ca}^{2+}$. Magnesium is one of the divalent ions, which has an active role in counteracting the effect of $\mathrm{Na}^{+}$and $\mathrm{Cl}^{-}$. Beside the presence of magnesium in chlorophyll, it activates many enzymes needed in photosynthesis, respiration and the formation of DNA and RNA (Salisbury and Ross, 2000). Phosphorous also decreased significantly under dry conditions. It is essential macronutrient that plays important roles as a structural and regulatory element in plant growth and development (Sacala et al., 2008). Some investigators reported that adequate phosphorous nutrition may minimize salt toxicity and ameliorate negative effects of water stress (Shubhra et al., 2004).

Table (1). Seasonal variations of some cations and anions (\%) as well as ash and fiber (\%) of the studied species.

\begin{tabular}{cccccccccccc}
\hline $\begin{array}{c}\text { Plant } \\
\text { species }\end{array}$ & Season & $\mathrm{Na}^{+}$ & $\mathrm{K}^{+}$ & $\mathrm{Ca}^{2+}$ & $\mathrm{Mg}^{2+}$ & $\mathrm{P}^{3+}$ & $\mathrm{Cl}^{-}$ & $\mathrm{SO}_{4}^{2-}$ & $\begin{array}{c}\text { Ash } \\
(\%)\end{array}$ & $\begin{array}{c}\text { Fiber } \\
(\%)\end{array}$ \\
\hline $\begin{array}{c}\text { Launaea } \\
\text { spinosa }\end{array}$ & Dry & $0.206^{*}$ & $0.384^{*}$ & 2.28 & 0.610 & 0.033 & $0.408^{*}$ & $0.120^{*}$ & $9.18^{*}$ & $43.2^{*}$ \\
\hline $\begin{array}{c}\text { Leptadenia } \\
\text { pyrotechnica }\end{array}$ & Wet & 0.191 & 0.333 & $3.33^{*}$ & $1.260^{*}$ & $0.043^{*}$ & 0.275 & 0.080 & 8.10 & 37.4 \\
\hline
\end{tabular}

Data are mean of three replicates.

*Significant differences between values of different parameters under dry and wet seasons, were found at $P \leq 0.01$ by Tukey's test (t-test).

Concentration of ash was significantly increased during dry season in $L$. spinosa than the wet season and this was associated with the increase of moisture stress. Similar result was reported by Khalefa et al. (2002). On the contrary, L. pyrotechnica attained higher values of ash concentration during the wet season than in dry ones. This result is in harmony with those of Reiad et al. 
(1996), and this indicates the higher absorption of minerals under water availability.

Concentration of fibers increased significantly during the dry season in the studied plant species. This result is in harmony with that obtained by Nour El-Din and Ahmed (2004), who found that Crotalaria aegyptiaca tend to increase its fiber concentration in the dry season than in the wet ones, which may be attributed to the lower moisture content during dry season.

\section{Concentration of Carbohydrate Fractions}

The highest level of total available carbohydrates was recorded in the wet season in both species (Table 2). This result may be attributed to the increase of growth rate in wet season relative to the dry ones. This result is in harmony with that obtained by Hegazi (2005). Under osmotic stress conditions, which causes cellular dehydration, plants try to maintain water content by accumulating compatible solutes (Patakas et al., 2002). The concentrations of reducing and non-reducing sugars in the studied species were significantly increased in the dry season compared with that of the wet season (Table 2). The plant's defense against drought stress requires osmotic adjustment, which can be achieved through the synthesis of intracellular solutes (Serrano et al., 1999), sugars and starch play a leading role in osmoprotection, osmotic adjustment, carbon storage and radical scavenging as well as stabilization of proteins and cell structures, signaling functions or induction of adaptive pathways (Arulbalachandran et al., 2009). Water stress is known to alter carbon assimilate partitioning between sucrose and starch, resulting in an increase in sucrose concentration. Patakas et al. (2002) reported an increase in sucrose concentration in stressed leaves as a consequence of greater sucrose synthesis plus starch degradation. Accumulation of compatible osmolytes, such as soluble (Table 2) sugars, in plants is an important osmoprotective mechanism (Zhi et al., 2009).

\section{Organic Acids and Free Thiols}

Organic acids were significantly increased in the dry season when compared with their concentration in the wet season (Table 3). This result is consistent with that obtained by Abdel Kawy (2015). Organic acids can be involved in various roles in the metabolic and physiological responses of plants to water stress, since solutes involved in osmotic adjustment are typically sugars, amino acids, inorganic ions and organic acids (Du et al., 2012).

Thiol compounds function as components of the intracellular and extracellular redox buffer (Iciek et al., 2004). There was a significant increase in

Egyptian J. Desert Res., 67, No. 2, 331-349 (2017) 
free thiol compounds during the dry season in both species compared with that of the wet season (Table 3). Free thiol concentration of L. pyrotechnica in dry season was 3 folds that of wet ones. Adaptation of sulfate uptake and assimilation is assumed to be a crucial determinant for plant survival in a wide range of adverse environmental conditions, since different sulfur containing compounds are involved in plant responses to both biotic and abiotic stresses (Rausch and Wachter, 2005).

Table (2). Seasonal variations in carbohydrate fractions (\%) of the studied species.

\begin{tabular}{|c|c|c|c|c|c|c|c|c|c|c|}
\hline \multirow[t]{2}{*}{$\begin{array}{c}\text { Plant } \\
\text { species }\end{array}$} & \multicolumn{2}{|c|}{$\begin{array}{c}\text { Total } \\
\text { carbohydrate } \\
(\%)\end{array}$} & \multicolumn{2}{|c|}{$\begin{array}{c}\text { Reducing sugar } \\
(\%)\end{array}$} & \multicolumn{2}{|c|}{$\begin{array}{c}\text { Non-reducing } \\
\text { sugar } \\
(\%)\end{array}$} & \multicolumn{2}{|c|}{$\begin{array}{c}\text { Soluble sugar } \\
(\%)\end{array}$} & \multicolumn{2}{|c|}{$\begin{array}{c}\text { Insoluble sugar } \\
(\%)\end{array}$} \\
\hline & Dry & Wet & Dry & Wet & Dry & Wet & Dry & Wet & Dry & Wet \\
\hline $\begin{array}{l}\text { Launaea } \\
\text { spinosa }\end{array}$ & 9.60 & $11.90^{*}$ & $0.679^{*}$ & 0.618 & $3.24^{*}$ & 2.75 & $3.92^{*}$ & 3.37 & 5.68 & $8.53^{*}$ \\
\hline $\begin{array}{c}\text { Leptadenia } \\
\text { pyrotechnica }\end{array}$ & 8.74 & $13.17^{*}$ & $0.579^{*}$ & 0.540 & $2.31^{*}$ & 2.05 & $2.88^{*}$ & 2.58 & 5.86 & $10.59^{*}$ \\
\hline
\end{tabular}

Data are mean of three replicates.

"Significant differences between values of different parameters under dry and wet seasons, were found at $P \leq 0.01$ by Tukey's test (t-test).

Table (3). Seasonal variations in organic acids (\%) and free thiols $(\mu \mathrm{M} / \mathrm{mg} \mathrm{FW})$ of the studied species.

\begin{tabular}{|c|c|c|c|c|}
\hline \multirow[t]{2}{*}{ Plant species } & \multicolumn{2}{|c|}{$\begin{array}{c}\text { Organic acids } \\
(\%)\end{array}$} & \multicolumn{2}{|c|}{$\begin{array}{l}\text { Free thiols } \\
(\mu \mathrm{M} / \mathrm{mg} \text { FW })\end{array}$} \\
\hline & Dry & Wet & Dry & Wet \\
\hline $\begin{array}{c}\text { Launaea } \\
\text { spinosa } \\
\end{array}$ & $10.50^{*}$ & 8.02 & $0.719^{*}$ & 0.544 \\
\hline $\begin{array}{c}\text { Leptadenia } \\
\text { pyrotechnica }\end{array}$ & $9.24^{*}$ & 7.78 & $1.060^{*}$ & 0.347 \\
\hline
\end{tabular}

\section{Phytohormones}

Concentrations of the different growth promoting hormones; i.e. auxins, gibberellins and cytokinins were significantly increased during the wet season 
relative to dry ones (Table 4) in both studied species. During the dry conditions, the concentrations of growth promoters were decreased due to the decrease in their biosynthesis and/or the increase in their degradation. Also, drought may induce the transformation of free active hormones to inactive bound forms (Farooq et al., 2009). A rapid decline in gibberellin activity was proportional to the duration and intensity of stress, and was also closely related to the rise in ABA content (Aharoni et al., 1977 and Hassanein et al., 2003). It was suggested that GA is involved in IAA synthesis or prevention of its degradation ( $\mathrm{Li}$ et al., 2003). Due to the polarity of most of phytohormones, their interaction with phospholipids, the main components of plant cell membranes, is possible (Gzyl et al., 2004). Under dry conditions, concentration of cytokinins in $L$. pyrotechnica was double that of L. spinosa, which matches with the results obtained by Abdel Kawy (2015), who revealed increased cytokinin concentration was concomitant with greater concentrations and activity of antioxidants, which may be due to protection against ROS. Cytokinins can delay leaf senescence directly by scavenging free radicals under abiotic stress (Grossman and Leshem, 2006).

Table (4). Seasonal variations in phytohormone concentrations of the studied species.

\begin{tabular}{ccccccc}
\hline \multirow{2}{*}{ Plant species } & \multicolumn{2}{c}{$\begin{array}{c}\text { Auxins } \\
(\mathbf{m g} / \mathbf{1 0 0} \text { g FW) }\end{array}$} & \multicolumn{2}{c}{$\begin{array}{c}\text { Gibberellins } \\
(\mathbf{m g} / 100 \text { g FW) }\end{array}$} & \multicolumn{2}{c}{$\begin{array}{c}\text { Cytokinins } \\
(\boldsymbol{\mu g} / \mathbf{1 0 0} \mathbf{g} \text { FW })\end{array}$} \\
\cline { 2 - 7 } & Dry & Wet & \multicolumn{1}{c}{ Dry } & Wet & Dry & Wet \\
\hline $\begin{array}{c}\text { Launaea } \\
\text { spinosa }\end{array}$ & 0.633 & $1.47^{*}$ & 4.69 & $7.51^{*}$ & 0.026 & $0.056^{*}$ \\
\hline $\begin{array}{c}\text { Leptadenia } \\
\text { pyrotechnica }\end{array}$ & 0.482 & $0.886^{*}$ & 5.37 & $6.93^{*}$ & 0.054 & $0.064^{*}$ \\
\hline
\end{tabular}

Data are mean of three replicates.

*Significant differences between values of different parameters under dry and wet seasons, were found at $P \leq 0.01$ by Tukey's test (t-test).

\section{Antimicrobial Activity}

Antimicrobial substances are substances that inhibit the growth and existence of microorganisms. These microorganisms could be pathogenic or nonpathogenic, hence, antimicrobial substances are used in the treatment of various ailments. A number of antimicrobial substances exist and they are gotten from diverse sources; such as microbial, plant, animal and chemical sources. 
Medicinal uses of these plants ranged from the administrations of the different plant's parts, to the use of extracts from the whole plant (Silva et al., 2012). It is clear that ethyl acetate extract imparts highly antimicrobial activity against all tested strains, chloroform and methanol extracts showed moderate antimicrobial activity, aqueous extract showed lower antimicrobial activity than the above extracts, while diethyl ether and acetone extracts found to be inactive against all tested strains under study (Fig.1-3). Nisa et al. (2013) reported that butanol extract of Rumex dentatus has strong antibacterial activity, while aqueous extract showed no activity against any of the bacterial strains. Meanwhile, aqueous extract showed maximum activity against Aspergillus flavus. Most extracts of $L$. pyrotechnica, particularly that of ethyl acetate showed little enhanced activity than that of L. spinosa.

Amongst the gram-positive and gram-negative bacteria, strains of gram positive bacteria were more susceptible to the extracts as compared with gramnegative bacteria (Parekh and Chanda, 2006). These differences may be attributed to the fact that the cell wall in gram-positive bacteria is of a single layer, whereas the gram-negative cell wall is multilayered structure (Yao and Moellering, 1995). The low sensitivity of bacteria may be due to their ability to form highly resistant resting stages called endospores. Drug-resistant strains of some bacteria and Candida albicans were found to be sensitive to the tested plant extracts. This indicates that antibiotic resistance does not interfere with the antimicrobial action of plant extracts and these extracts might have different modes of action on tested organisms (Dahiya and Purkayastha, 2012). Each of ethyl acetate, chloroform, methanol and aqueous extracts of L. spinosa, $L$. pyrotechnica and its latex were active against three out of the four tested fungal organisms. The exception was found to be natural resistance of this fungus to these extracts (Okwori et al., 2008). The antifungal activities and cytoprotective effect of medicinal plants are attributed to the presence of flavonoids, tannins and phenolic compounds (Abdallah et al., 2015). The traditional healers make use of water primarily as a solvent, but our study showed that, different extracts of both plants and latex were much better and powerful. This may be due to the better solubility of the active components in organic solvents and the polarity of the constituents being extracted by each solvent (Felhi et al., 2017).

Egyptian J. Desert Res., 67, No. 2, 331-349 (2017) 


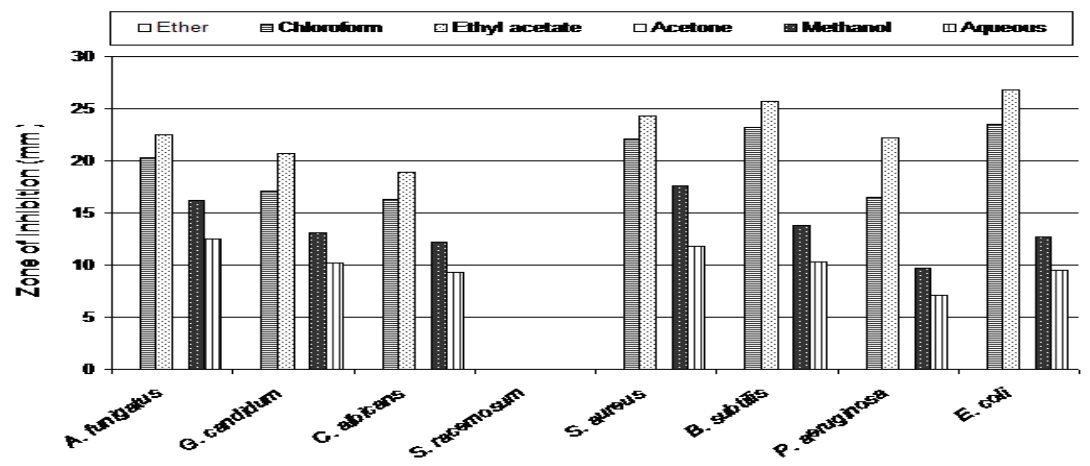

Fig. (1). Zone of inhibition (mm) of various extracts of the aerial parts of Launaea spinosa.

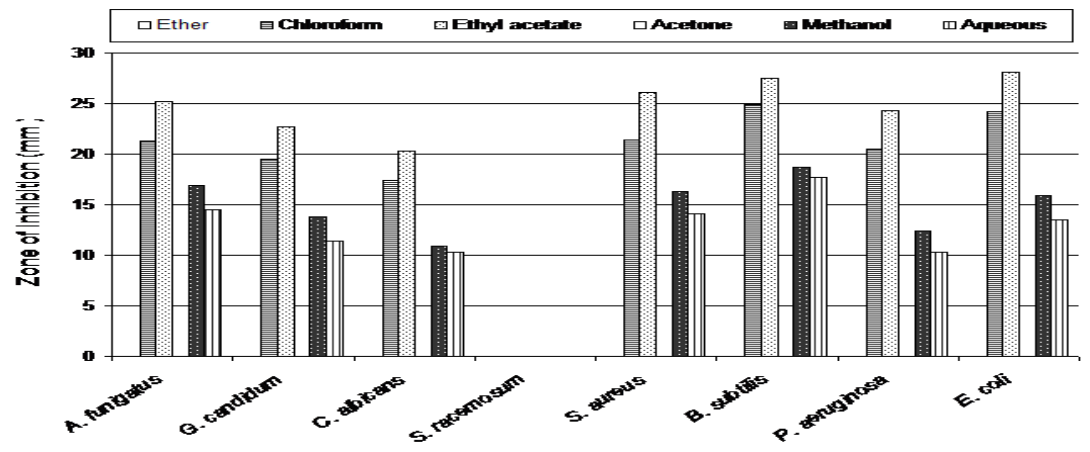

Fig. (2). Zone of inhibition (mm) of various extracts of the aerial parts of Leptadenia pyrotechnica.

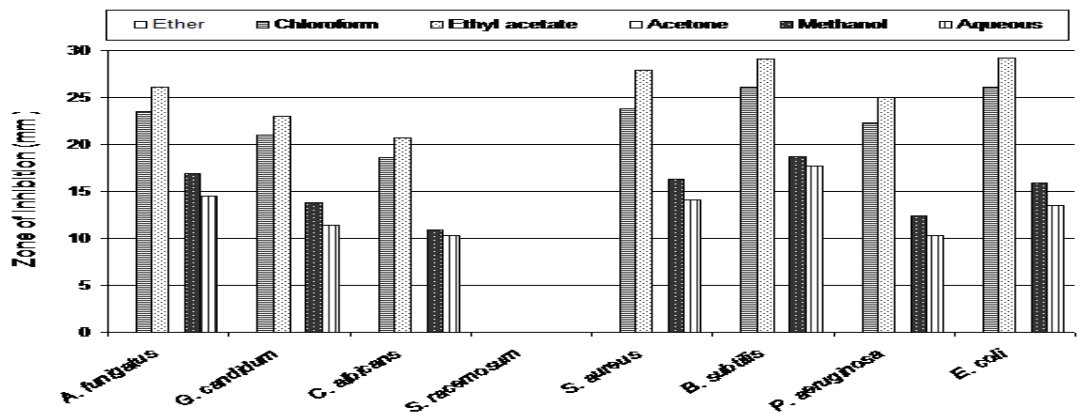

Fig. (3). Zone of inhibition (mm) of various extracts of latex of Leptadenia pyrotechnica.

Egyptian J. Desert Res., 67, No. 2, 331-349 (2017) 


\section{CONCLUSION AND RECOMMENDATION}

Osmotic adjustment (osmoregulation) of the studied species was achieved through accumulation of inorganic ions and compatible organic solutes during dry conditions. There is a correlation between the increased cytokinins, antioxidants and antimicrobial activity. Both species displayed high antimicrobial activity, which can be used for many purposes. The contamination of food by microorganisms is a worldwide public health concern problems, extracts of medicinal plants can be used to prevent the food borne microorganisms as a tool of preservatives during food processing and for new drug synthesis.

\section{REFERENCES}

Abdallah, H., M. Farag, S. Osman, D. Kim, K. Kang, C.H. Pan and E. AbdelSattar (2015). Isolation of major phenolics from Launaea spinosa and their protective effect on HepG2 cells damaged with t-BHP. Pharma. Biol., 54 (3): 536-541.

Abdel Fattah, H., A. Zaghlou, A. Halim and E. Waight (1990). Steroidal and triterpenoid constituents of Launaea resedifolia L. Egypt. J. Pharm. Sci., 31: 81-91.

Abdel Kawy, A.H. (2015). Ecophysiological studies on metabolic activities and antioxidant enzymes in some naturally growing plants under drought and salinity stresses in the North Western and Eastern coasts of Egypt. Ph.D. Thesis, Bot. Dept., Fac. Sci., Ain Shams Univ., Cairo, Egypt.

Aharoni, N., A. Blumenfeld and A.E. Richmound (1977). Hormonal activity in detached lettuce leaves as affected by leaf water content. Plant Physiol, 59: 1169-1173.

Anderson, K.J., S.S. Teuber, A. Gobeille, et al. (2001).Walnut polyphenolics inhibit in vitro human plasma and LDL oxidation. J. Nutr. 131: 2837-42.

A.O.A.C. (2000). In "Official Methods of Analysis", $17^{\text {th }}$ Ed. Association of Official Analytical Chemists. Washington D.C., USA.

Arulbalachandran, D., K.G. Sankar and A. Subramani (2009). Changes in metabolites and antioxidant enzyme activity of three Vigna species induced by $\mathrm{NaCl}$ stress. Am. Eurasian. J. Agron., 2 (2): 109-116.

Box, S. and D.P. Schachtman (2000). The effect of low concentrations of sodium 
on potassium uptake and growth of wheat. Aust. J. Plant Physiol., 27: $175-182$.

British Pharmacopoeia (1980). Published on the recommendation of the Medicine Commission. Cambridge, UK, Vol. 11, pp. 561.

Chaplin, M.F. and J.F. Kennedy (1994). In "Carbohydrate Analysis". A practical Approach. $2^{\text {nd }}$ Ed. Oxford University Press, Oxford, New York, Tokyo, pp. 324.

Dahiya, P and Sh. Purkayastha (2012). Phytochemical screening and antimicrobial activity of some medicinal plants against multi-drug resistant bacteria from clinical isolates. Indian J. Pharm. Sci., 74 (5): 443-450.

Du, H., Z. Wang, W. Yu and B. Huang (2012). Metabolic responses of hybrid Bermudagrass to short-term and long-term drought stress. J. Amer. Soc. Hort. Sci., 137 (6): 411-420.

El-Bassuony, A.A. and N.M. Abdel-Hamid (2006). Antibacterial coumarins isolated from Launaea spinosa (Forssk). Plant. Med. Phytother., 26: 358-374.

Ellman, G.L. (1959). Tissue sulfhydryl groups. Archives Biochem. Biophys., 82: 70-77.

Elumalai, R.P., P. Nagpal and J.W. Reed (2002). A mutation in the Arabidopsis KT2/JUP2 potassium transporter gene officer shoot cell. Plant Cell, 14: $119-131$.

Farooq, M., A. Wahid, N. Kobayashi, D. Fujita and S.M.A. Basra (2009). Plant drought stress: effects, mechanisms and management. Agron. Sustain. Dev., 29: 185-212.

Felhi, S., A. Daoud, H. Hajlaoui, K. Mnafgui, N. Gharsallah and A. Adri (2017). Solvent extraction effects on phytochemical constituents profiles, antioxidant and antimicrobial activities and functional group analysis of Ecballium elaterium seeds and peels fruits. Food Sci. Technol, Campinas, 37 (3): 483-492.

Fletcher, R.A. and D.Mc Cullagh (1971). Cytokinin induced chlorophyll formation in cucumber cotyledons. Planta (Bert.), 101: 88-90.

Gazit, S. and A. Blumenfeld (1970). Cytokinin and inhibitor activities in the avocado fruit mesocarp. Plant Physiol., 46: 334.

Graham, H.D. and J.H.M. Henderson (1961). Reaction of gibberellic acid and gibberellins with folin phosphomolybdic acid reagent and its use for quantitative assay. Plant Physiol., 3: 405-408.

Grossman, S. and Y. Leshem (2006). Lowering of endogenous lipoxygenase

Egyptian J. Desert Res., 67, No. 2, 331-349 (2017) 
activity in Pisum sativum foliage by cytokinin as related to senescence. Physiol. Plant., 43: 359-362.

Gzyl, B., M. Filek and A. Dudek (2004). Influence of temperature on phytohormone interactions with monolyres obtained from phospholipids of wheat calli. Plant Physiol., 59: 60-64.

Harbor, A. and T. Aasheim (1962). A spectrophotometric method for the identification and assay of tryptophol and other indole derivatives. Physiol., Plant., 15: 546-551.

Hare, P.D., W.A. Cress and V. Staden (1997). The involvement of cytokinins in plant responses to environmental stress. Plant Growth Regul., 23: 79-103.

Hassanein, R.A., A.M. Youssef, A.A. Hassanein and A.A. Morsy (2003). Lipid composition and phytohormonal contents of some halophytes in relation to soil characteristics of the red sea and Sinai Peninsula, Egypt. J. Environ Sci., 25: 207-236.

Hegazi, Gh.A. (2005). Ecophysiological and biotechnological studies on endangered plants from Sinai Peninsula. Ph.D. Thesis, Bot. Dept., Fac. Sci., Ain Shams Univ., Cairo, Egypt.

Hopkins, W.G. and N.P.A. Hüner (2004). In "Introduction to Plant Physiology". John Wiley and Sons, Inc.

Humphries, E.C. (1956). Mineral Composition and Ash Analysis. In: Modern Methods of Plant Analysis. (Peach, K. and M.B. Tracy Ed.). Springer-Verleg, Berlin, pp. 148.

Iciek , M., G. Chwatko, E.L. Koci, E. Bald and L. Wlodek (2004). Plasma levels of total, free and protein bound thiol as well as sulfane sulfur in different age groups of rats. Acta Biochm. Polon., 51 (3): 815-824.

Ismaeil, S.M., Z.A. Khidr and A.H. Abd El-Kawy (2006). Ecophysiological studies on some species growing along (Wadi El Natrun-El Alamein) desert road. El Azhar Bull., Sci., 17 (1): 69-86.

Jackson, W. A. and G.W. Thomas (1960). Effect of KCl and dolometic limestone on growth and ion uptake of sweet potato. Soil Sci., 89: 347-352.

Kareem, S.O., I. Akpan and O.P. Ojo (2008). Antimicrobial activities of Calotropis procera on selected pathogenic microorganisms. Afri. J. Biomed. Res., 11: $105-110$.

Khalefa, S.F., I.A. Tolba, B.S. Abd-El-Nasser and T.S. Mahdy (2002). Autecological studies on Heliotropium arabinense fres. J. Environ. Studies Res., Ain Shams University, 4 (2): 389-414.

Khan, R.A., M.R. Khan, M. Ahmed et al. (2012). Hepatoprotection with a 
chloroform extract of Launaea procumbens against CCl4-induced injuries in rats. BMC Complem. Alternat. Med., 12: 114.

Khidr, Z.A., S.M. Ismaeil and A.H. Abd El- Kawy (2007). Hydrophilic amino acids rich-protein, proline and low molecular mass proteins as osmoprotectants for some Egyptian xerophytés grown under various habitat conditions. Egypt. J. Biotech., 26: 37-55.

Kirnak, H., C. Kaya, D. Higgs and I. Tas (2003). Responses of drip irrigated bell pepper to water stress and different nitrogen levels with or without mulch cover. J. Plant Nutr., 26: 263-277.

Li, X., S. Li and J. Lin (2003). Effect of $\mathrm{GA}_{3}$ spraying on lignin and auxin contents and the correlated enzyme activities in bayberry (Myrica rubra Bieb.) during flower-bud induction Plant Sci., 164: 549-556.

McLaughlin, S. P. (2006). Vascular floras of Sonoita state natural Atea and San Rafael state. Park: Arizona's First Natyral Area Parks Brit. SIDA, 22: 661-704.

Mishra, M.K., P. Tiwari, D.K. Dash, S. Rajesh, G.l Jadon, G. Ghosh and B.B. Bank (2010). Antifungal activity of Leptadenia reticulate wight and Arn. Aerial parts. Int. J. Phytomedicine, 2: 172-176.

Morsy, A, R.A. Hassanein, N.M. Nour El-Din, A.H. Abdel Kawy (2016). Adaptive mechanisms of Asphodelus aestivus Brot. to withstand drought stress: metabolic constituents and activity of antioxidant enzymes. Egypt. J. Bot., 56: 225-241.

Nisa, H, A.N. Kamili, S.A. Bandh, S.U. Amin, B.A. Lone and J.A. Parray (2013). Phytochemical screening, antimicrobial and antioxidant efficacy of different extracts of Rumex dentatus L. - A locally used medicinal herb of Kashmir Himalaya. Asian Pacific J. Tropic. Disease, 3 (6): 434-440.

Nocito, F.F., C. Kancilli, B. Giacomini and G.A. Sacchi (2007). Sulfur metabolism and cadmium stress in higher plants. Stress, 1 (2): 142156.

Nour El-Din, N.M. and F.A. Ahmed (2004). Effect of seasonal variation on secondary metabolites and nutritive value of Crotalaria aegyptiaca Benth. Egypt. J. Desert Res., 54 (1): 121-139.

Okwori, A.E.J., C.I. Okeke, A. Uzoechina, N.S. Etukudoh, M.N. Amali, J.A. Adetunji and A.O. Olabode (2008). The antibacterial potentials of Nauclea latifolia. J. Biotech., 7 (10): 1394.

Panwara, J. and J.C. Tarafdarb (2006). Distribution of three endangered medicinal plant species and their colonization with arbuscular

Egyptian J. Desert Res., 67, No. 2, 331-349 (2017) 
mycorrhizal fungi. J. Arid Environ., 65: 337-350.

Parekh, J. and S. Chanda (2006). In vitro antimicrobial activities of extracts of Launaea procumbens Roxb. (Labiateae), Vitis vinifera L. (Vitaceae) and Cyperus rotundus L. (Cyperaceae). Afric. J. Biomed. Res., 9: $89-93$.

Patakas, A., N. Nikolaou, E. Zioziou, K. Radoglou and B. Noitsakis (2002). The role of organic solute and ion accumulation in osmotic adjustment in drought stressed grapevines, Plant Sci., 163: 361-367.

Rahman, A., M.I. Choudhary and W.J. Thomsen (2001). In "Bioassay Techniques for Development". Harwood Academic Publishers, the Netherlands, pp. 16.

Rathore, H.S., S. Mitta and S. Kumar (2000). Synthesis, characterization and antifungal activities of 3d-transition metal complexes of 1acetylpiperazinyldithiocarbamate, M(acpdtc)2. Pesticide. Res. J., 12: 103-107.

Rausch, T. and A. Wachter (2005). Sulfur metabolism: a versatile platform for launch defence operation. Trends Plant Sci., 10: 503-509.

Reiad, M.S., M.A. Ashoub, I.B. Abo-Deya, M.S. El-Hakeem and K.M. Ahmed (1996). Environmental effect on yield and quality of five plant associations of the north western coast of Egypt. Annals Agric. Sci., Moshtohor, 34 (1): 37-52.

Rowell, D.L. (1994). In "Soil Science Methods and Applications". Longman Publishers, Singapors, pp. 350.

Sacala, E., A. Demczuk, E. Grzys and Z. Spiak (2008). Effect of salt and water stresses on growth, nitrogen and phosphorus metabolism in Cucumis sativus L. Seedling. Acta Soc. Bot. Polo., 77 (1): 23-28.

Said, A. and M. I. Naguib (1964). Sucrose determination as a mean of estimation of the draw back taxon exported Halwa Tehinia. Bull. Fac. Sci., Cairo Univ., 39: 207.

Salama, F., M. Abd El-Ghani, N. El-Tayeh, A. Amro and S. El-Naggar (2017). Some aspects of drought resistance in Citrullus colocynthis L. in the Egyptian deserts. Taeckholmia, 37: 52-66.

Salisbury, F.B. and C.W. Ross (2000). In "Plant Physiology". $5^{\text {th }}$ Ed., Wadsworth Publishing Company, Inc. Belmont. California.

Scholz, F.G., S.J. Bucci, N. Arias, F.C. Meinzer and G. Goldstein (2012). Osmotic and elastic adjustments in cold desert shrubs differing in rooting depth: coping with drought and subzero temperatures. Oecologia, 170: 885-897. 
Serrano, R., C.F. Macia and V. Moreno (1999). Genetic engineering of salt and drought tolerance with yeast regulatory genes. J. Am. Soc. Horti. Sci., 78: 261-269.

Sharma, S.D., K. Sahu, G.K. Chandrol, P.K. Jian and V. Sharma (2016). Ethnobotanical survey of five villages of Durg District of Chhattisgarh,(India). Int. J. Adv. Res. Biol. Sci., 3: 104-110.

Shubhra, Dayal, J., C.L. Goswami and R. Mungal (2004). Influence of phosphorus application on water relations, biochemical parameters and gum content in cluster bean under water deficit. Biol. Plant., 48: 445-448.

Silva, N.C., L. Barbosa, L.N. Seito and A. Jr. Fernandes (2012). Antimicrobial activity and phytochemical analysis of crude extracts and essential oils from medicinal plants. Nat. Prod. Res., 26 (16): 1510-14.

Smith, D., G.M. Poulsen and C.A. Raguse (1964). Extraction of total available carbohydrates from grass and legume tissues. Plant Physiol., 39: 960-969.

Umbrient, W. W., R.H. Burries, J.F. Stauffer, P.P. Coheen, W.I. Johnson, G.AI. Leepage, V.R. Patter and W.C. Schneider (1969). In "Manometric Techniques, A Manual Describing Methods Applicable to the Study of Tissue Metabolism". $4^{\text {th }}$ Ed. Burgess Publishing Company, Mineapolis, pp. 239.

Vahdati, K. and N. Lotfi (2013). Abiotic stress tolerance in plants with emphasizing on drought and salinity stresses in Walnut. Licensee, In Tech. C., 10: 307-365.

Wang, S.M., C.G. Wan, Y.R. Wang, H. Chen, Z.Y. Zhou, H. Fu and R.E. Sosebee (2004). The characteristics of $\mathrm{Na}^{+}, \mathrm{K}^{+}$and free proline distribution in several drought resistant plants of the Alxa Desert, China. J. Arid Environ, 56(3): 525-539.

Waraich, E., A. Ahmed, R. Saifullah, M. Ashraf and Y. Ehsanullah (2011). Role of mineral nutrition in alleviation of drought stress in plants. A.J.C.S. 5(6): 764-777.

Yao, J. and R. Moellering (1995). Antimicrobial Agents. In: "Manual of Clinical Microbiology". (Murray, P., E. Baron, M. Pfaller, F. Tenover and R. Yolken Eds). Asm., Washington DC, p. 1281-1290.

Zhi, W., Z. Yan, W. Lili, L. Xia, L. Xiu, J. Phillips and D. Xin (2009). A WRKY transcription factor participates, in dehydration tolerance in Boea hygrometrica by binding to the W-box elements of the galactinol synthase (BhGo1S1) promoter. Planta, 230 (6): 1155-1166.

Egyptian J. Desert Res., 67, No. 2, 331-349 (2017) 


\section{الإنضباط الإسموزي والنشاط المضاد للميكروبات لنوعين من النباتات

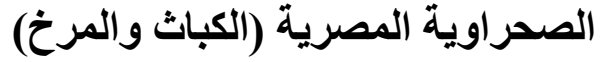

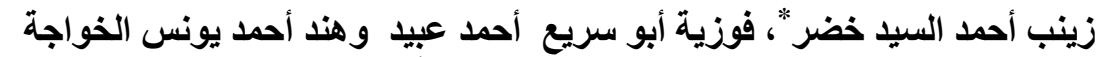

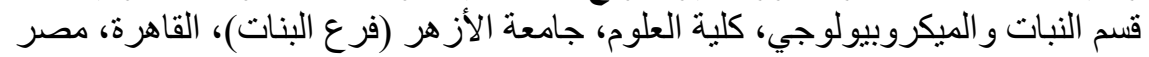

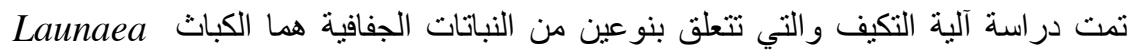

spinosa

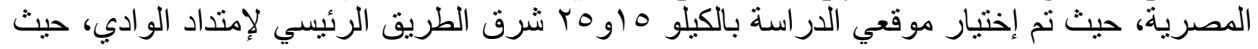

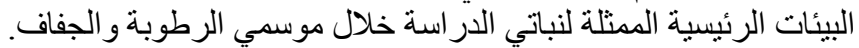

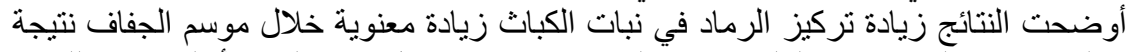

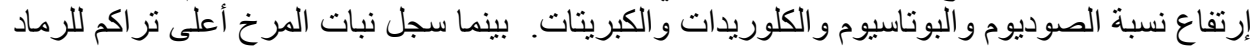

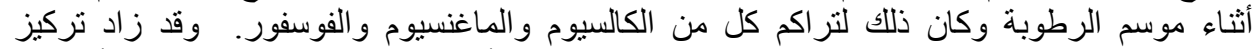

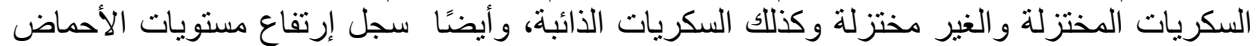

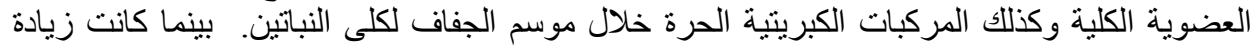

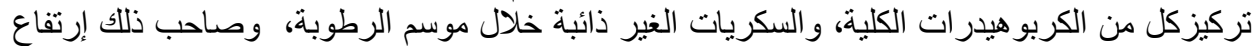

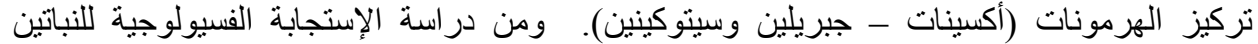

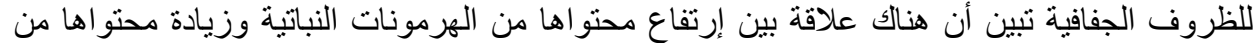

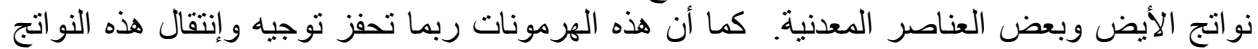

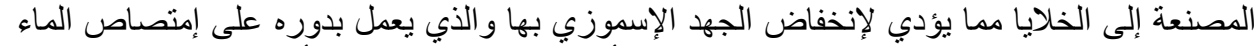

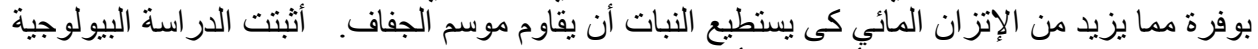

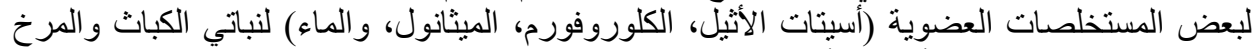

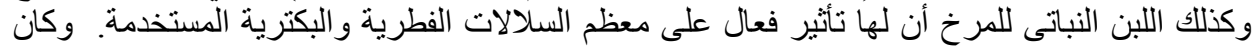

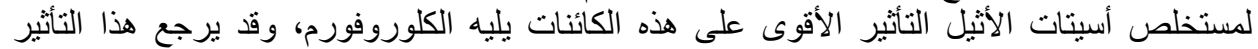
لإحتو ائها على بعض المواد الفعالة، ومن الممكن أن يكون لها إستخدام تطبيقي آمن. 